Gitation: Salinas-Cruz, E., RuízÁlvarez O., Martínez-Sánchez, J., Cadena- Íñiguez, Pedro, ReynosoSantos, R. \& Espinosa-Paz, Néstor. (2021). Optimal fertilization dose in castor bean (Ricinus communis L.) using partial budgets analysis. Agro Productividad. https://doi.org/10.32854/ agrop.v14il1.2174

Editor in Chief: Dr. Jorge Cadena Iñiguez

Received: February 16, 2021. Accepted: October 27, 2021. Published on-line: November 30, 2021.

This work is licensed under a Creative Commons Attribution-NonCommercial 4.0 International license.

\section{Optimal fertilization dose in castor bean (Ricinus communis L.) using partial budgets analysis}

\author{
Salinas-Cruz, E. ${ }^{1}$; Ruíz-Álvarez O. ${ }^{1}$; Martínez-Sánchez, $\mathrm{J}^{1}{ }^{\text {; }}$ Cadena- Íñiguez, Pedro ${ }^{{ }^{*}}$; \\ Reynoso-Santos, R. ${ }^{1}$; Espinosa-Paz, Néstor ${ }^{+}$ \\ ${ }^{1}$ Instituto Nacional de Investigaciones Forestales, Agrícolas y Pecuarias. Campo Experimental Centro de \\ Chiapas. km 3.0 Carretera Ocozocoautla-Cintalapa, C.P.29140, Ocozocoautla de Espinosa, Chiapas. \\ * Correspondence: cadena.pedro@inifap.gob.mx
}

\begin{abstract}
Objective: To determine the economically adequate fertilization dose for a castor bean (Ricinus communis L.) crop that improves the producer's benefits using the partial budgeting technique.

Design/methodology/approach: The experiment was established at a site located $500 \mathrm{~m}$ from the Centro de Chiapas experimental field, with an altitude of $800 \mathrm{~m}$. Two production factors were studied: nitrogen (40, 60 , and 80 ) and phosphorus (20,40, and 60) with three levels each. The treatments had nine combinations in a randomized complete block experimental design and four replications. Phenological and morphological variables, seed yield, and variable costs economic components were evaluated as a response.

Results: With the average yields the obtained net benefits were determined; an adjustment of the benefits was made, and its dominance was determined. Four experiments were dominated, and five showed favorable profits for the producer. The 80-60-00 formulation had a return rate (RR) of 23\%.

Conclusions: The 40-20-00, 40-40-00, 40-60-00, 80-40-00 and 80-60-00 formulations were dominant. The 80-60-00 formulation reported the highest RR, an increase in variable cost of US $\$ 9.64$, like other doses of lower costs and benefits. For this dose, the net benefits increase was US $\$ 222.61$.
\end{abstract}

Keywords: Ricinus communis, variable costs, net benefit, return rate.

\section{INTRODUCTION}

The optimization of resources is key to increasing net profits within the agricultural production process. Within this production process, fertilizers cover between 20 and 37\% of total production costs (Salinas et al., 2017); for this reason, its correct use is essential to maintain a balance in the benefit-cost relationship, in addition to contributing to the reduction of the emission of pollutants into the environment. Due to the increase in the food demand caused by population growth, many farmers put more pressure on the land, without concerning an adequate return of nutrients; others fertilize in excess and abuse their use. From agricultural fields fertilization, some fertilizing elements have a detrimental impact on stratospheric chemistry, thus worsening regional and global climate 
change (IPCC, 2013). Therefore, the development and implementation of methodologies and techniques to reduce emissions from agricultural land are an urgent need.

In intensive agriculture, even when the used fertilizers volumes are calculated from a soil diagnosis and the yield to be obtained, an economic approach must be added to precisely know how that fertilizer dose maximizes the efficiency of all the financial resources. Thus, an economically optimal dose is defined as the amount of fertilizer that maximizes the crop's profitability (Nelson et al., 1985; Pagani et al., 2008). In this sense, Salvagiotti et al. (2011) comment that a way to calculate the economically optimal dose that maximizes resources is through the adjustment of response curves between fertilizer doses and yield. In this way, it uses the first derivative of the function to calculate the economic response of each level of applied fertilizer. According to Cerrato and Blackmer (1990), the optimal economic dose can also be estimated using the quadratic and exponential models, the Linear-Plateau model, and the Quadratic-Plauteau model. The economically optimal dose of fertilizer should be established with practical methods for farmers; so using the aforementioned methods would not provide results with the desired characteristics.

Other authors suggest using the partial budgeting technique. Partial budgeting is a tool used to evaluate the costs and benefits associated with a specific change in a farm; it is a planning and decision-making framework used to compare the costs and benefits of the alternatives faced by an agricultural company (Soha, 2014). Soha (2014) used partial budgets to estimate the effect on the net benefit of changing from one nitrogen fertilization level to another; also evaluated the costs and benefits associated with a specific change. Shaaban and Kisetu (2014) used partial budgets to evaluate the response of the Irish potato to NPK-based fertilization applications and its economic rate of return when grown in a Ultisol. For their part, Agumas et al. (2014) evaluated the response of irrigated onions to different nitrogen and phosphorus doses in northwestern Ethiopia.

At the same time, the world is faced with the need to incorporate new raw materials options for biofuels production. Currently, there is a downward trend in hydrocarbon production, mainly due to increased exploration and extraction costs, reservoir depletion, regulation of environmental impact, and effects on the climate. Faced with this situation, renewable energies, besides being friendlier to health and the climate than fossil fuels, facilitate access to electricity with a lower cost advantage (Kühne et al., 2019). In this sense, castor bean (Ricinus communis) is an attractive option for biodiesel production. Some of its genotypes have a great capacity to produce excellent quality oil as an input for biodiesel. The main advantages of castor oil are that it preserves its viscosity at high temperatures and resists low temperatures without freezing, it comes from a renewable source, it is non-toxic, non-flammable, easy to transport, biodegradable, sustainable, and sulfur and aromatic compounds free (Raya-Pérez et al., 2016). Another advantage is its drought tolerant and adapted to a great diversity of climates (Barrios-Gómez et al., 2018). Due to the great adaptation potential of castor bean to the Mexican climates and the state of Chiapas, and to the degree is adopted as an industrial crop, its technological package could be complemented with an economically optimal dose of fertilization; This would undoubtedly support low-income producers' economy, as well as help them to conserve the soils of their plots. 
The objective of this research was to determine the economically optimal dose of fertilization for castor bean cultivation using the partial budget technique. The information in this research will be useful for farmers and companies dedicated to the cultivation of this species in the state of Chiapas. Above all, it will help to calculate the fertilizer's volumes, and to reduce the possibility of capital flight and pollution of natural resources.

\section{MATERIALS AND METHODS}

\section{Experiment location}

The castor bean experiment was established at Ocozocoautla de Espinosa, Chiapas, Mexico (16 $46^{\circ} \mathrm{N}$ and $93^{\circ} 22^{\prime} \mathrm{W}$, at $800 \mathrm{~m}$ ). The soil is sandy-clayey in texture, light brown when dry, and with a $5 \%$ slope. The climate is Aw type, warm humid with rains in summer, and subject to midsummer drought effects.

\section{Treatments description}

Two production factors were studied: nitrogen and phosphorus; each with three levels, for nitrogen 40, 60, and 80; while for phosphorus 20, 40, and 60. The treatments were a combinatorial arrangement with nine combinations total (Table 1). The experimental design was randomized complete blocks with four repetitions.

\section{Partial budgets}

Partial budget is a methodology that only takes into account the costs associated with the decision to use a treatment or not (Reyes, 2001). This technique is based on the principle that small changes in the production system could generate one or more of the following effects (Duque-Orrego, 2005):

1) Originate additional costs; 2) Eliminate or reduce some returns; 3) Originate additional returns; 4) Eliminate or reduce some costs In this research, the partial budgeting technique was applied following the recommendations of the International Maize and Wheat Improvement Center (CIMMYT, 1988).

Table 1. Evaluated fertilization treatments, nitrogen $(\mathrm{N})$ and phosphorus $(\mathrm{P})$.

\begin{tabular}{c|c|c}
\hline \multirow{2}{*}{$\mathbf{T}$} & $\mathbf{N}$ & $\mathbf{P}$ \\
\cline { 2 - 3 } & \multicolumn{2}{|c}{$\left(\mathbf{k g ~ h a}^{-\mathbf{1}}\right)$} \\
\hline 1 & 40 & 20 \\
\hline 2 & 60 & 20 \\
\hline 3 & 80 & 20 \\
\hline 4 & 40 & 40 \\
\hline 5 & 60 & 40 \\
\hline 6 & 80 & 40 \\
\hline 7 & 40 & 60 \\
\hline 8 & 60 & 60 \\
\hline 9 & 80 & 60 \\
\hline
\end{tabular}




\section{RESULTS AND DISGUSSION}

\section{Variable costs}

Table 2 shows the variable costs per treatment, the costs generated by the urea application plus that of DAP fertilizer are considered; to these market costs, the cost of transporting the product are added, then adding both to establish the field cost considered in the partial costs analysis as the one disbursed by the producer, according to the variable cost. The highest value purchase product was urea. The doses varied for each treatment. The treatments were formed with a dose of urea and another dose of DAP, so the sum of both was the total variable cost for the nine treatments.

The first 40-20-00 (N-P-K) treatment generated the lowest costs. In general, the varying costs ranged from US\$ 69.65 to US\$ 79.1, with two urea and one of DAP applications. The highest costs are found in the 80-40-00 and 80-60-00 treatments with urea applications of 139 and $123 \mathrm{~kg}$ and DBH of 86 and $130 \mathrm{~kg}$ respectively; therefore, the total of US\$ 99.1 and US\$108.75 was paid.

\section{Economic profit and adjusted profit}

Calculating the economic benefits was based on the yield obtained per treatment for the purchase price of castor seed, which was US\$ 0.46 per kilogram sold in the year of the analysis; the yields obtained are presented in Table 3 for each treatment according to the applied fertilization dose.

According to the obtained data, treatment 9, with doses of DAP and urea 80 and 60 respectively yielded $2.1 \mathrm{t} \mathrm{ha}^{-1}$, the highest benefit, with a total of US\$945, although it was also the one that disbursed the highest costs; while treatment 3, the one with the lowest yield, with $124 \mathrm{~kg}$, and therefore had the lowest net economic obtained benefit, in addition to the generated costs were a total of US \$ 89.65, which means that it was not the treatment with the lowest profit and production, it was the one with the lowest gender cost.

After calculating the net benefit and according to the process, an adjustment is made to the net benefit, this can vary from 10 to $25 \%$ according to the recommendation (CIMMYT,

Table 2. Variable costs by applied treatment.

\begin{tabular}{|c|c|c|c|c|c|c|c|c|}
\hline \multirow[b]{2}{*}{$\mathbf{n}^{\circ}$} & \multirow{2}{*}{$\begin{array}{c}\text { Description } \\
\left(\mathrm{kg} \mathrm{ha}^{-1}\right)\end{array}$} & \multicolumn{2}{|c|}{ Quantity } & \multicolumn{2}{|c|}{ Unit cost } & \multicolumn{2}{|c|}{ Number of applications } & \multirow{2}{*}{$\begin{array}{c}\text { Total } \\
\text { variable } \\
\text { costs US }\end{array}$} \\
\hline & & urea $(\mathbf{k g})$ & DAP $(\mathbf{k g})$ & $\begin{array}{c}\text { urea } \\
\text { (US \$/kg) }\end{array}$ & $\begin{array}{c}\text { DAP } \\
(\mathbf{U S} \$ / \mathbf{k g})\end{array}$ & urea $(\mathbf{k g})$ & DAP (kg) & \\
\hline 1 & $40-20-00$ & 69.65 & 43.47 & 0.46 & 0.4 & 2 & 1 & 49.42 \\
\hline 2 & $60-20-00$ & 113.43 & 43.7 & 0.46 & 0.4 & 2 & 1 & 69.65 \\
\hline 3 & $80-20-00$ & 156.91 & 43.7 & 0.46 & 0.4 & 2 & 1 & 89.65 \\
\hline 4 & $40-40-00$ & 52.93 & 86.95 & 0.46 & 0.4 & 2 & 1 & 59.12 \\
\hline 5 & $60-40-00$ & 96.41 & 86.95 & 0.46 & 0.4 & 2 & 1 & 79.12 \\
\hline 6 & $80-40-00$ & 139.89 & 86.95 & 0.46 & 0.4 & 2 & 1 & 99.12 \\
\hline 7 & $40-60-00$ & 36.08 & 130.43 & 0.46 & 0.4 & 2 & 1 & 68.76 \\
\hline 8 & $60-60-00$ & 79.56 & 130.43 & 0.46 & 0.4 & 2 & 1 & 88.76 \\
\hline 9 & 80-60-00 & 123.05 & 130.43 & 0.46 & 0.4 & 2 & 1 & 108.77 \\
\hline
\end{tabular}

DAP: Diammonium phosphate. 
Table 3. Economic benefit for established treatment.

\begin{tabular}{c|c|c|c}
\hline Number & $\begin{array}{c}\text { Description } \\
\left(\mathbf{k g ~ h a}^{-\mathbf{1}}\right)\end{array}$ & $\begin{array}{c}\text { Yield } \\
\left(\mathbf{t ~ h a}^{-\mathbf{1}}\right)\end{array}$ & $\begin{array}{c}\text { Economic benefit } \\
\text { US\$ }\end{array}$ \\
\hline 1 & $40-20-00$ & 0.704 & 316.80 \\
\hline 2 & $60-20-00$ & 0.904 & 406.80 \\
\hline 3 & $80-20-00$ & 0.124 & 55.80 \\
\hline 4 & $40-40-00$ & 0.841 & 378.45 \\
\hline 5 & $60-40-00$ & 0.984 & 442.80 \\
\hline 6 & $80-40-00$ & 1.518 & 683.10 \\
\hline 7 & $40-60-00$ & 1.03 & 463.50 \\
\hline 8 & $60-60-00$ & 1.2 & 540.00 \\
\hline 9 & $80-60-00$ & 2.1 & 945.00 \\
\hline
\end{tabular}

1988). The adjustment made was $15 \%$, which was calculated on the initial net profit and subsequently subtracted from this income, resulting in the adjusted net profit (Table 4).

\section{Dominance analysis}

By definition, the first treatment is not dominated (Reyes, 2001); later, when going from treatment 1 to 4 , it is observed if there is an increase in benefits because this treatment was considered not dominated, from treatment 4 to treatment 7 there is an increase, which is why it is considered not dominated. It was found that from treatment 7 to treatment 2 the net benefit is lower and therefore considered dominated (Table 5).

By having a dominated treatment, treatment 7 was used as not dominated and it was determined that treatment 5 is dominated, therefore, treatment 7 will continue to be the basis for determining the following treatments. Treatment 8 is not mastered, while Treatment 3 is mastered. Treatments 6 and 9 are not dominated.

According to Table 4, fertilization with the 80-20-00 combination had variable costs of US\$ 89.65 and a net benefit of US\$ 51.91, which represents a high cost and a low net benefit, unlike the other different fertilization doses.

Table 4. Adjusted economic benefit.

\begin{tabular}{c|c|c|c|c}
\hline Number & $\begin{array}{c}\text { Description } \\
\left(\mathbf{k g ~ h a} \mathbf{~}^{-\mathbf{1}}\right)\end{array}$ & $\begin{array}{c}\text { Economic benefit } \\
\text { US\$ }\end{array}$ & $\begin{array}{c}\text { Adjustment to 15\% } \\
\text { US\$ }\end{array}$ & $\begin{array}{c}\text { Adjusted economic } \\
\text { benefit US\$ }\end{array}$ \\
\hline 1 & $40-20-00$ & 316.80 & 47.52 & 269.28 \\
\hline 2 & $60-20-00$ & 406.80 & 61.02 & 345.78 \\
\hline 3 & $80-20-00$ & 55.80 & 8.37 & 47.43 \\
\hline 4 & $40-40-00$ & 378.45 & 56.77 & 321.68 \\
\hline 5 & $60-40-00$ & 442.80 & 66.42 & 376.38 \\
\hline 6 & $80-40-00$ & 683.10 & 102.47 & 580.64 \\
\hline 7 & $40-60-00$ & 463.50 & 69.53 & 393.98 \\
\hline 8 & $60-60-00$ & 540.00 & 81.00 & 459.00 \\
\hline 9 & $80-60-00$ & 945.00 & 141.75 & 803.25 \\
\hline
\end{tabular}


Table 5. Dominance analysis.

\begin{tabular}{c|c|c|c|c|l}
\hline Number & $\begin{array}{c}\text { Description } \\
\left(\mathbf{k g ~ h a} \mathbf{~}^{-1}\right)\end{array}$ & $\begin{array}{c}\text { Costs that vary } \\
(\mathbf{G V}) \mathbf{U S} \$\end{array}$ & $\begin{array}{c}\text { Net profit } \mathbf{N P}) \\
\mathbf{U S} \mathbf{\$}\end{array}$ & $\begin{array}{c}\text { Observation of } \\
\text { treatment change }\end{array}$ & $\begin{array}{c}\text { Conclusion of the } \\
\text { observation }\end{array}$ \\
\hline 1 & $40-20-00$ & 49.427 & 269.28 & & not dominated \\
\hline 4 & $40-40-00$ & 59.128 & 321.6825 & De 1 a 4 & not dominated \\
\hline 7 & $40-60-00$ & 68.769 & 393.975 & De 4 a 7 & not dominated \\
\hline 2 & $60-20-00$ & 69.658 & 345.78 & De 7 a 2 & dominated \\
\hline 5 & $60-40-00$ & 79.1285 & 376.38 & De 2 a 5 & dominated \\
\hline 8 & $60-60-00$ & 88.7695 & 459 & De 5 a 8 & not dominated \\
\hline 3 & $80-20-00$ & 89.6585 & 47.43 & De 8 a 3 & dominated \\
\hline 6 & $80-40-00$ & 99.1295 & 580.635 & De 3 a 6 & not dominated \\
\hline 9 & $80-60-00$ & 108.775 & 803.25 & De 6 a 9 & not dominated \\
\hline
\end{tabular}

\section{Rate of return}

The rate of return is established through the increases in the net economic costs and benefits, for its calculation, only the non-dominated treatments are considered, which for this case would be those described in the following Table 6 .

Partial budgets can be used when there is a minimum change in agricultural activity and generally these changes are carried out in a short term, seeking to evaluate the change in both income and expenses (Santilla-Simbaña, 2020); such is the case of the analysis that was carried out to the fertilization changes in castor bean trials to determine the optimal dose is technically and economically most viable to obtain the lowest cost and the greatest benefit.

In this analysis, the variable costs are determined based on the use of fertilizers according to the dose or treatment, determining their field costs. These vary with the production and are intended to be less than the economic benefits to be obtained, since it could only be economic to continue production in the short term, as long as the income is greater than the costs of production variable (Cooperative Extension, 2021).

\section{GONGLUSIONS}

The treatment with the highest costs was the 80-40-00 dose (US\$ 99.12) and the 80$60-00$ (US\$ 188.77), from these treatments the obtained economic benefits were US\$

Table 6. Rate of return of the different treatments.

\begin{tabular}{c|c|c|c|c|c|c}
\hline Number & $\begin{array}{c}\text { Description } \\
\left(\mathbf{k g} \mathbf{~ h a}^{-1}\right)\end{array}$ & $\begin{array}{c}\text { Costs That } \\
\text { vary }(\mathbf{C V}) \mathbf{U S} \$\end{array}$ & $\begin{array}{c}\text { Net profit } \\
(\mathbf{N P}) \text { US\$ }\end{array}$ & $\begin{array}{c}\text { Increase in } \\
\text { NP US\$ }\end{array}$ & $\begin{array}{c}\text { Increase in } \\
\text { GV US\$ }\end{array}$ & TRM (\%) \\
\hline 1 & $40-20-00$ & 49.427 & 269.28 & & & \\
\hline 4 & $40-40-00$ & 59.128 & 321.6825 & 52.40 & 9.70 & 5.40 \\
\hline 7 & $40-60-00$ & 68.769 & 393.975 & 72.29 & 9.64 & 7.50 \\
\hline 8 & $60-60-00$ & 88.7695 & 459 & 65.03 & 20.00 & 3.25 \\
\hline 6 & $80-40-00$ & 99.1295 & 580.65 & 121.64 & 30.36 & 4.01 \\
\hline 9 & $80-60-00$ & 108.775 & 803.25 & 222.62 & 9.65 & 23.08 \\
\hline
\end{tabular}


683.1 and US\$ 945, with yields of 1.5 and 2.1 ton per hectare respectively. According to the dominance analysis, treatments 40-20-00, 40-40-00, 40-60-00, 80-40-00, and 8060-00 presented no dominance, so they could be the optimal doses for fertilization in the production of castor bean. In the rate of return analysis, it is determined that the 80-60-00 dose is the economic optimum because the cost increase was only US\$9.64 equivalent to the 40-40-00 and 40-60-00 treatments. the treatment with the highest cost variation was 80-40-00 with a total of US\$ 30.36. While the benefits increase is presented in the 80-6000 treatment with US $\$ 222.61$. According to the partial budget methodology, the optimal economic treatment is the 80-60-00 since their costs increase are low and the net benefit is greater than that of the rest of the recommended doses.

\section{REFERENGES}

Agumas B., Abewa A. and Abebe D. (2014). Response of Irrigated Onion (Allium cepa L.) to Nitrogen and Phosphorus Fertilizers at Ribb and Koga Irrigation Schemes in Amhara Region, North western Ethiopia, International Research Journal of Agricultural Science and Soil Science. 4(5). 95-100.

Barrios- Gómez, E. J., Canul- Ku, J., Hernández- Arenas, M. G., Solís- Bonilla, J. L., (2018). Evaluación de dos ciclos de higuerilla en Morelos, México: siembra y rebrote. Revista Mexicana de Ciencias Agrícolas. Volumen 9 (8): 1663-1673. Doi: 10.29312/remexca.v9i8.679

Cerrato M. E., Blackmer A. M. (1990). Comparison of models for describing corn yield response to nitrogen fertilizer. Agronomy Journal. 82(1). 138-143.

CIMMYT. (1998). La formulación de recomendaciones a partir de datos agronómicos: Un manual metodológico de evaluación económica. Edición completamente revisada. México D. F., México: CIMMYT.

Cooperative Extension. 2021. Presupuestos para tomar decisiones agrícolas. PennState Extensión. Alternativas Agrícolas. P. 12.

Duque-Orrego, H., Posada-Suárez, H.E., Alvarado-Alvarado, G. (2005). Análisis económico de la adopción de las variedades castillo regionales resistentes a la roya. Cenicafé. 56(3). 197-215.

Kühne, K., Sánchez, L., Roth, J., Tornel, G., Gerasimchuk I. (2019). Más allá de los combustibles fósiles: Transición fiscal en México. The International Institute for Sustainable Development, Manitoba, Canada. P. 49.

Nelson L. A., Voss R. D., Pesek J. (1985). Agronomic and statistical evaluation of fertilizer response. In: OP Engelstad (ed.) Fertilizer technology and use. Pp 53-90. ASA. Madison - Wisconsin - USA.

Pagani A., Echeverria H. E., Sainz Rozas H. y PA Barbieri. (2008). Dosis óptima económica de nitrógeno en maíz bajo siembra directa en el Sudeste bonaerense. Ciencia del Suelo. 26(2). 179-188.

Reyes-Hernández. M. (2001). Análisis económico de experimentos agrícolas con presupuestos parciales: Reenseñando el uso de este enfoque. Centro de Información Agro socioeconómica. Boletín informativo $1-200, \mathrm{p}-33$.

Salvagiotti F., Castellarin J. M., Ferrugati F. J., Pedro H. M. (201 1). Dosis optima económica de nitrógeno en maíz según potencial de producción y disponibilidad de nitrógeno en la región Pampeana norte. Ciencia del suelo. 29 (2).199-212.

Santilla-Simbaña. K. M. (2020). Desarrollo de manual para presupuestos parciales para el proceso de toma de decisiones agrícolas. Escuela Agrícola Panamericana. Carrera de administración de agronegocios. Zamorano, Honduras.

Shaaban H., Kisetu E. (2014). Response of Irish potato to NPK fertilizer application and its economic return when grown on an Ultisol of Morogoro, Tanzania. Journal of Agricultural and Crop Research. 2 (9). 188196.

Soha M. E.-D. 2014. The partial budget analysis for sorghum farm in Sinai Peninsula, Egypt. Annals of Agricultural Sciences. 59(1). 77-81. Doi:10.1016/j.aoas.2014.06.011 